\title{
The Relationship of Abnormal Audit Fees and Accruals: Bargain Power or Cost Control?
}

\author{
Honghui Zhang \\ School of Accountancy, Jiangxi University of Finance and Economics, Nanchang, China \\ Email: danordio@163.com
}

How to cite this paper: Zhang, H.H. (2017) The Relationship of Abnormal Audit Fees and Accruals: Bargain Power or Cost Control? Open Journal of Accounting, 6, 82-94.

https://doi.org/10.4236/ojacct.2017.63007

Received: June 9, 2017

Accepted: July 2, 2017

Published: July 5, 2017

Copyright $\odot 2017$ by author and Scientific Research Publishing Inc. This work is licensed under the Creative Commons Attribution International License (CC BY 4.0).

http://creativecommons.org/licenses/by/4.0/

\begin{abstract}
This paper uses the empirical data of listed companies in China from 2007 to 2013 to examine the relationships between abnormal audit fees and accruals (audit quality), and tries to find out the mechanism and the consequences of abnormal audit fees affecting accruals (audit quality). The research found that abnormal audit fees were negatively correlated with accruals. After taking the positive and negative nature of the abnormal audit expenses into consideration, research found that the abnormal audit fee reflects the economic bond between the auditor and the company, which impair the independence of auditors and degrade the audit quality. Negative audit fees reflect strong bargaining power of companies, and lower audit fees impel auditors to reduce audit effort, control audit costs to achieve a certain profit target, which will also degrade audit quality.
\end{abstract}

\section{Keywords}

Audit Fees, Abnormal Expenses, Auditors, Audit Quality

\section{Introduction}

The financial report auditing is the joint effort of the company and the auditor, which requires the company, the auditor to negotiate and bargain in the course of the audit [1]. Understanding the auditor's compromise in audit quality is an essential topic of concern to academics and practitioners. One possible explanation is that the auditor's employment and the audit fee payment depend on the company. This economic dependency reduces the independence of auditor and increases the likelihood of the auditors' acquiescence of company's earnings management. However, the yield to the company's requirements of earnings management is costly; it may expand the legal risk of the entire firm, and even lead to the churn of existing customer base. For example, "Enron events" led to the churn of Anderson's customer base, and finally collapsed; these contingent 
audit risk requires the company to compensate the auditor, therefore audit fees are at a premium. What's more, audit fees may be given below normal levels. Since companies have strong bargaining power, they are only willing to pay less for audit fees [2]. Less audit fees will make auditors to reduce audit effort and control costs to achieve necessary profits, which can result in the reduction of audit quality.

As for study on audit fees, there has been a large amount of domestic researches; a series of literature studied the influence factors and economic consequences of audit fees. However, related researches on abnormal audit fees are just at the initial stage. Based on the idea, Chen et al. [3] studied the relationship between abnormal audit fees, adverse audit results improvement and audit opinion shopping. However, domestic research focuses only on positive abnormal audit fees, ignoring negative abnormal audit fees, and there are few researches on the relationship between abnormal audit costs and audit quality. But these are the emphasis of current foreign research [4]. Research from foreign scholar shows that positive abnormal audit fees can impair the audit quality [5], negative anomaly audit fees can also jeopardize audit quality [6]. To verify whether there is such a situation in Chinese audit market, empirical data should be tested for analysis.

Based on the empirical data of Chinese listed companies, this paper analyzes the relationship between abnormal audit fees and audit quality. It is found that the abnormal audit fees and the audit quality are negatively correlated. After considering the positive and negative nature of the abnormal audit fees, result shows that the independence of auditors can be decreased by abnormal audit fees, and the auditor's economic dependence on entrusting company leads to the impairment of audit quality. Besides, negative abnormal audit fees reflect the company's strong bargaining power, but lower audit fees impel auditors to reduce audit efforts, control audit costs to ensure a certain profit, which will also jeopardize the audit quality. This paper studies audit quality from the perspective of abnormal audit fees, expands the literature of abnormal audit fees and audit quality, which gives reference to the improvement of the audit fee rule.

\section{Literature Review and Assumptions}

The study of audit fees mainly focuses on its influencing factors, such as corporate-level factors and firm-level factors, to examine the impact of these factors on audit fees. Simunic [7] innovatively pointed out that audit fees are related to factors such as company scale, financial leverage, and inventory. Subsequently, some scholars extended the research on audit fees to the audit committee, internal control [8], firm consolidation and other fields. Domestic research on audit fees also started with corporate-level factors and firm-level factors. As for corporate-level factors, Zhang [9] found companies' own asset scale is one of the main factors affecting the audit fees. Other research studied audit fees based on factors such as corporate governance, internal control. For the firm's level, Li et al. [10] studied the impact of the firm's merger on audit fees; Liu studied the 
impact of firm's being punished on audit fees. Other research studied the issue of audit fees from the perspective of media attention, product market competition.

Existing domestic literature is more concerned about audit fees, but seldom focuses on the abnormal audit fees. Auditors may receive audit fees under normal level when providing audit services and may also charge too high a fee. However, overseas scholars have already made research on abnormal audit fees, such as DeAngelo [11] pointed out that the auditor is economically dependent on their customer, and they may maintain good relationship with their customer to obtain "quasi-rents", such that the independence of the auditors are jeopardized by abnormal audit fees, finally negatively influence the audit quality. After that, a series of studies explored the impact of abnormal audit fees on audit quality, there was no significant relationship between abnormal audit fees and auditors' going concern opinion. Larcker and Richardson [12] used the data from 2000-2001 to study the relationship between audit quality (absolute value of the discretionary accruals ) and abnormal audit charges, and found that the increase of abnormal audit fees led to a decline in audit quality. Chen [3] argues that an increase in abnormal audit charges will lead to an improvement in adverse audit results and an increase in audited accounting earnings. Fang and Hong [13] also found that abnormal audit is positively related to the improvement of adverse audit results, and the company's audit opinion changes from adverse opinion or disclaimer of opinion to current year's other types of audit opinion. Based on the above analysis, the hypothesis 1 is proposed.

Hypothesis 1: Ceteris paribus, the higher the abnormal audit costs, the lower the audit quality.

Although the above-mentioned domestic studies suggest that changes in abnormal audit fees may lead to opinion shopping and other acts, but ignore the positive and negative nature of audit fees. Foreign literature has already studied its influence on audit quality. For positive abnormal audit fees, general studies have argued that economic dependence on entrusting companies leads auditors to abandon the implementation of adequate professional prudence to correctly interpret audit evidence or to make impartial judgments. Excessively high abnormal audit fees will lead to a decrease in the auditor independence. Audit fee beyond normal level was given by companies to make auditors acquiesce its earnings management, which will finally affect audit quality. Krishnan et al. [5] found that there was a significant negative correlation between abnormal audit fees and earnings response coefficients, indicating that abnormal audit fees would affect audit quality negatively. Hribar et al. [14] found that abnormal audit fees are positively correlated with financial restatement, accounting malpractice, and SEC comments letter during 2002 to 2007. The above studies are all discussing the impact of positive abnormal audit fees on audit quality. For negative abnormal audit fees, Asthana and Boone [6] argue that negative abnormal audit fees reflect the company's bargaining power, and it is negatively correlated with audit fees. The bargaining power mainly affects companies' audit quality 
from the following two aspects: on the one hand, since financial report auditing is the result of the bargaining of the auditor and the company, the company will use its own bargaining power to implement earnings management in a certain degree without violating the GAAP, and the stronger the company's ability to bargain, the greater the degree of earnings management, which will ultimately lower the quality of the audit. On the other hand, excessive low audit fees will impel the auditor's to reduce audit effort and cut necessary audit procedures, which severely damaged audit quality. Blankley et al. [15] also found that excessive low audit fees dampen audit efforts and are more likely to cause financial restatements. Based on the above analysis, Hypothesis $2 \mathrm{a}$ and $2 \mathrm{~b}$ are proposed.

Hypothesis 2a: Ceteris paribus, the higher the abnormal audit fees, the lower the audit quality.

Hypothesis 2b: Ceteris paribus, the higher the negative abnormal audit fees, the lower the audit quality.

\section{Research Design}

\subsection{Data Sources and Data Filtering}

This paper uses the China CSMAR database to collect the financial data and audit data of China listed companies from 2007 to 2013. After obtaining the data of all listed companies in the database, the following screening procedures are implemented: (1) Remove listed companies with incomplete annual data from 2003 to 2007. (2) Remove listed companies that issue B shares or H shares simultaneously. These companies' research results may be alienated because they are multiply supervised. (3) Remove listed companies that are categorized as ST, PT in certain year or continuous year. (4) Remove companies with abnormal indicators. Whether the accountancy firm is big10 is the control variables in this article and the data are obtained from the CICPA's firm ranking. The final number of samples is 9959 . Table 1 shows the definition of variables.

\subsection{Regression Model}

There are two ways to measure the amount of abnormal audit fees, one is to establish the expected audit fees model, and use the regression residuals to indicate abnormal audit fees, such as, Asthana and Boone, Blankley et al., etc.; the other is to examine the annual changes of audit fees, and use the changes to indicate abnormal audit fees, such as Fang and Hong. In this paper, we use the former method to measure the abnormal audit fees, and the former one to do robustness check.

$$
\begin{aligned}
\text { Lnfee }= & \beta_{0}+\beta_{1} \text { Big10 }+\beta_{2} \text { Op }+\beta_{3} \text { Inv }+\beta_{4} \text { Rec }+\beta_{5} \text { Em }+\beta_{6} \text { Chang } \\
& +\beta_{7} \text { Sqsub }+\beta_{8} \text { Roa }+\beta_{9} \text { Lev }+\beta_{10} \text { Sale }+\beta_{11} \text { Ind } / \text { Year }+\kappa
\end{aligned}
$$

In the above model, Lnfee represents the audit fee, expressed in natural logarithm; Big10 is the dummy variable of "the top 10 firm", when the firm belongs to Big ten, its value is 1 , otherwise 0 ; Op represents the audit opinion, the modified audit opinion is 1 , otherwise 0 ; Inv is the inventory level, with the inventory 
Table 1. Definition of variables.

\begin{tabular}{|c|c|c|}
\hline Variable type & Variable name & Variable interpretation \\
\hline \multirow{3}{*}{$\begin{array}{l}\text { Dependent } \\
\text { variables }\end{array}$} & IDal & Audit quality, the absolute value of earnings \\
\hline & |Da| & management level, calculated according to Dechow et al. \\
\hline & Cscore & $\begin{array}{l}\text { Audit quality, indicated by accounting conservatism, which is } \\
\text { calculated by the model of Khan and Watts [17] }\end{array}$ \\
\hline \multirow{3}{*}{$\begin{array}{l}\text { Independent } \\
\text { variables }\end{array}$} & Lnfee & Audit fees, expressed in natural logarithm \\
\hline & Resfee & Abnormal audit fees, the residual of the model (1) \\
\hline & Dlnfee & Abnormal audit fees, annual change value of natural logarithm \\
\hline \multirow{10}{*}{$\begin{array}{c}\text { Control } \\
\text { variables }\end{array}$} & Big10 & $\begin{array}{c}\text { Dummy variables of Big ten, it is } 1 \text { when the firm is big ten; } \\
\text { otherwise } 0 .\end{array}$ \\
\hline & Op & Audit opinion. 1 for modified audit opinion, 0 otherwise. \\
\hline & Inv & Inventory level. Inventory divided by total asset. \\
\hline & $\operatorname{Rec}$ & $\begin{array}{l}\text { Account receivable level. Account receivable divided by the total } \\
\text { assets. }\end{array}$ \\
\hline & Em & $\begin{array}{c}\text { Earnings management tendency. } 1 \text { for the occurrence of annual } \\
\text { loss last year, } 0 \text { otherwise. }\end{array}$ \\
\hline & Change & Firm change, 1 for the occurrence of firm change, 0 otherwise \\
\hline & Sqsub & $\begin{array}{c}\text { The complexity of audit service, indicated by the number of } \\
\text { company segments. }\end{array}$ \\
\hline & Roa & Profitability, measured by company's return on total assets. \\
\hline & Lev & Financial leverage, measured by asset-liability ratio. \\
\hline & Sale & $\begin{array}{c}\text { Company scale, measured by the natural logarithm } \\
\text { of sales revenue. }\end{array}$ \\
\hline
\end{tabular}

divided by the total asset; Rec represents accounts receivable, with accounts receivable divided by the total asset; Em represents earnings management tendencies, its value is 1 when company suffer annual losses last year, , Otherwise 0; Change indicates the firm changes, if changed, the value is 1, otherwise 0; Sqsub shows the complexity of audit service, it calculated as the square root of the number of company segments; Roa is the company's total return on assets; Lev is the company's asset-liability ratio; Sale is the natural logarithm of the company's sales revenue; Year is the annual dummy variable; Ind is the industry dummy variable. The regression residual of the model (1) indicates abnormal audit fees, named as Resfee.

$$
\begin{aligned}
|\mathrm{Da}|= & \alpha_{0}+\alpha_{1} \text { Resfee }+\alpha_{2} \text { Big10 }+\alpha_{3} \text { Inv }+\alpha_{4} \text { Sqsub } \\
& +\alpha_{5} \text { Roa }+\alpha_{6} \text { Lev }+\alpha_{7} \text { Cashf }+\alpha_{8} \text { Ind } / \text { Year }+\theta
\end{aligned}
$$

In this model, $|\mathrm{Da}|$ is the absolute value of the earnings management level, it is calculated according to the method of Dechow et al. [16], which represents the audit quality; Resfee is the abnormal audit fees, calculated according to model (1); the other variables are interpreted in the same way as the above-mentioned.

\subsection{Descriptive Statistical Analysis and Univariate Analysis}

Before implementing empirical analysis, the main continuous variables are winsorized. As it is shown in Table 2, $|\mathrm{Da}|$ represents audit quality, which is the 
Table 2. Descriptive statistics.

\begin{tabular}{cccccc}
\hline Variable & Mean & Median & Std. error & Minimum & Maximum \\
\hline Da $\mid$ & 0.2145 & 0.0880 & 0.3768 & $6.87 \mathrm{e}-07$ & 2.0771 \\
Resfee & 0 & -0.0791 & 0.6637 & -4.1199 & 4.2135 \\
Lnfee & 13.4891 & 13.3342 & 0.7647 & 9.2103 & 18.3694 \\
Lev & 0.4786 & 0.4906 & 0.2087 & 0.0518 & 0.9164 \\
Roa & 0.0678 & 0.0707 & 0.1209 & -0.5857 & 0.3765 \\
Cashf & 0.0443 & 0.0443 & 0.0784 & -0.2034 & 0.2581 \\
Inv & 0.1774 & 0.1339 & 0.1662 & 0 & 0.9426 \\
Big10 & 0.4549 & 0 & 0.4980 & 0 & 1 \\
Sqsub & 2.1571 & 2 & 0.6218 & 1 & 7.6811 \\
Em & 0.0791 & 0 & 0.2699 & 0 & 1 \\
Rec & 0.0912 & 0.0618 & 0.0939 & 0 & 0.6776 \\
Change & 0.1116 & 0 & 0.3149 & 0 & 1 \\
Op & 0.0304 & 0 & 0.1717 & 0 & 1 \\
Dlnfee & 0.1045 & 0 & 0.2573 & -4.2812 & 5.2470 \\
Cscore & 0.0112 & 0.0109 & 0.0879 & -0.5919 & 0.4247 \\
\hline & & & & & \\
\hline
\end{tabular}

absolute value of earnings management level, the maximum value of $|\mathrm{Da}|$ is 2.0771 and the minimum is close to 0 . Resfee represents abnormal audit fees, with the maximum value of 4.2135 and the minimum value of -4.1199 , indicating that some firms charge higher than expected levels of audit fees, while some companies are below expected levels. The result of Lnfee for audit fees varies greatly, with a maximum of 18.3694, a minimum of 9.2103 and a standard deviation of 0.7647 . In other variables, Sqsub for the complexity of the audit business has obvious otherness, with a standard deviation of 0.6218 and Cscore has a maximum of 0.4247 , a minimum -0.5919 and a mean of 0.0109 , which is less than the mean in Khan and Watts (2009), indicating that the accounting conservatism of listed companies in our country is less than that of US listed companies.

In Table 3, according to the median of the abnormal audit fees (Resfee and Dlnfee), sample companies were divided into two sub-samples, which were lower than the median and higher than the median. For $|\mathrm{Da}|$ it can be seen that, Resfee sample with high abnormal audit fee has higher mean and median than the low, and it also has highly significant T-statistic of -4.4790 and Wilcoxon signed rank test value of -5.154 , indicating that there are significant differences between different abnormal audit fees samples. As for the audit quality expressed in Cscore, the accounting conservatism of the high Resfee samples has negative mean and median, suggesting that sample companies with high abnormal audit fee do not have conservatism. Accordingly, the positive mean and median of the low Resfee samples' accounting robustness undoubtedly indicate that sample firms with low abnormal audit fees have accounting conservatism, and the $\mathrm{T}$ test value and the Wilcoxon signed rank test value are highly significant. 
Similarly, in the two sub-samples of Dlnfee, the mean and median value of the high Dlnfee samples were higher than those of the low, and the T-statistic and the Wilcoxon signed rank test also were highly significant. The differential test in Table 3 shows that there is a significant difference in companies' audit quality under different levels of abnormal audit fees, which initially confirms our hypothesis.

\section{Regression Analysis}

In order to verify the hypothesis of this paper, regression is performed according to the regression model (2). The results are as follows. In Table 4, the regression (1) considers the influence of abnormal audit fees plus the company's financial indicators on the audit quality. In this regression, the regression coefficient of the abnormal audit fees (Resfee) is 0.0719 , which is highly significant, indicating that an increase of $1 \%$ of the abnormal audit fee will lead to $|\mathrm{Da}|$ 's growth of 7.19 percent. Since the dependent variable $|\mathrm{Da}|$ is the inverse indicator of the audit quality, the economic meaning of the regression (1) is that the audit quality is reduced by $7.19 \%$ for every $1 \%$ increase of the abnormal audit fee, which verifies the hypothesis 1 . The regression (2) considers the impact of abnormal audit fees plus the audit-related indicators on the audit quality. The regression coefficient of the abnormal audit fee is 0.0719 , with high significance at 1 percent, and the regression result is consistent with the regression (1), confirming the hypothesis 1. In regression (3), all variables were put into the regression equation, and the regression coefficient of Resfee is 0.0719 and is highly significant, which is also consistent with the previous regression (1), regression (2), similarly confirms the hypothesis 1 . However, the control variables vary in regression (1), regression (2) and regression (3), which directly results in the difference between the Fstatistic and the coefficient of determination in the regression model. In regression (4), the independent variable is positive abnormal audit fees, with a highly significant regression coefficient of 0.0736 , indicating that the positive abnormal audit fees lead to a decline in corporate audit quality, which confirms the hypothesis $2 \mathrm{a}$ of this paper. It also suggests that companies impair the auditor's

Table 3. Differences in audit quality under different standards.

\begin{tabular}{|c|c|c|c|c|c|c|}
\hline & \multicolumn{2}{|c|}{ High Resfee } & \multicolumn{2}{|c|}{ Low Resfee } & t-statistic & Wilcoxon \\
\hline \multirow{2}{*}{$\begin{array}{c}\text { Audit quality } \\
\text { Da }\end{array}$} & Mean & Median & Mean & Median & \multirow{2}{*}{$-4.4790^{\star * *}$} & \multirow{2}{*}{$-5.154^{\star * *}$} \\
\hline & 0.0311 & 0.0161 & -0.0085 & 0.0054 & & \\
\hline \multirow{4}{*}{$\begin{array}{c}\text { Audit quality } \\
\text { Cscore }\end{array}$} & \multicolumn{2}{|c|}{ High Resfee } & \multicolumn{2}{|c|}{ Low Resfee } & & \\
\hline & Mean & Median & Mean & Median & \multirow{2}{*}{$25.4984^{* * *}$} & \multirow{2}{*}{$24.456^{\star * *}$} \\
\hline & -0.0187 & -0.0185 & 0.0405 & 0.0371 & & \\
\hline & \multicolumn{2}{|c|}{ High Dlnfee } & \multicolumn{2}{|c|}{ Low Dlnfee } & $\mathrm{t}$-statistic & Wilcoxon \\
\hline \multirow{2}{*}{$\begin{array}{c}\text { Audit quality } \\
\mathrm{Da}\end{array}$} & Mean & Median & Mean & Median & \multirow{2}{*}{$-5.1395^{\star * *}$} & \multirow{2}{*}{$-5.762^{\star * *}$} \\
\hline & 0.0291 & 0.0151 & -0.0176 & 0.0045 & & \\
\hline
\end{tabular}

Note: Significance (two-tailed) at: ${ }^{\star} 0.10,{ }^{*}{ }^{\star} 0.05$ and ${ }^{* *} 0.01$ levels, respectively. 
Table 4. Abnormal audit fees and audit quality.

\begin{tabular}{cccccc}
\hline & All Resfee & All Resfee & All Resfee & Resfee $>0$ & Resfee $<0$ \\
\hline \multirow{2}{*}{ Resfee } & $(1)$ & $(2)$ & $(3)$ & $(4)$ & $(5)$ \\
& $0.0719^{* * *}$ & $0.0719^{* * *}$ & $0.0719^{* * *}$ & $0.0736^{* * *}$ & $0.0384^{* * *}$ \\
Lev & $(13.41)$ & $(13.24)$ & $(13.42)$ & $(6.49)$ & $(2.83)$ \\
& $0.3053^{* * *}$ & & $0.3096^{* * *}$ & $0.4061^{* * *}$ & $0.2104^{* * *}$ \\
Roa & $(16.41)$ & & $(16.13)$ & $(11.72)$ & $(9.40)$ \\
& $0.1417^{* * *}$ & & $0.1470^{* * *}$ & $0.2164^{* * *}$ & $0.1007^{* * *}$ \\
Cashf & $(4.55)$ & & $(4.69)$ & $(4.01)$ & $(2.76)$ \\
& 0.0333 & & 0.0105 & 0.0708 & -0.0648 \\
Big10 & $(0.67)$ & & $(0.21)$ & $(0.76)$ & $(-1.17)$ \\
& & $0.0211^{* * *}$ & $0.173^{* *}$ & 0.0185 & $0.0157^{*}$ \\
Inv & $(2.83)$ & $(2.35)$ & $(1.37)$ & $(1.80)$ \\
& & $0.0479^{*}$ & $-0.0657^{* *}$ & -0.0645 & $-0.0742^{* *}$ \\
Sqsub & $(1.66)$ & $(-2.19)$ & $(-1.20)$ & $(-2.21)$ \\
& & $0.0213^{* * *}$ & $0.125^{* * *}$ & 0.0185 & 0.0062 \\
con & $(3.62)$ & $(2.14)$ & $(1.37)$ & $(0.94)$ \\
& & $0.0578^{* *}$ & $-0.0929^{* * *}$ & $-0.1779^{* * *}$ & -0.0191 \\
Ind & $(-3.11)$ & $(2.54)$ & $(-3.77)$ & $(-4.15)$ & $(-0.67)$ \\
Year & control & control & control & control & control \\
f & control & control & control & control & control \\
adj & $54.15^{* * *}$ & $44.54^{* * *}$ & $49.73^{* * *}$ & $28.33^{* * *}$ & $19.26^{* * *}$ \\
n & 0.1425 & 0.1198 & 0.1435 & 0.1759 & 0.1009 \\
& 9599 & 9599 & 9599 & 4228 & 5371 \\
\hline
\end{tabular}

Notes: Significance (two-tailed) at: ${ }^{*} 0.10,{ }^{*} 0.05$ and ${ }^{* * *} 0.01$ levels, respectively.

independence by paying auditors positive abnormal audit fees to satisfy the earnings management objectives. In regression (5), the independent variable is negative abnormal audit fees, with a significant regression coefficient of 0.0384 , indicating that negative abnormal audit fees also lead to a decline in corporate audit quality, which well confirms the hypothesis $2 b$, verifies that excessively low audit costs impel auditors to reduce audit effort and finally jeopardize audit quality. This regression result also confirms the impact of companies' bargaining power on audit quality. The conclusion of regression (4) and regression (5) is consistent with that of Asthana and Boone (2012), therefore this paper argues that abnormal audit fees will reduce audit quality for Chinese listed companies.

In the control variables, the financial leverage (Lev) and the audit quality is negatively correlated. The cash return rate (Roa) has a negative correlation with the audit quality. Cashflow (cashf) has no significant correlation with the audit quality. The regression coefficients of the big 10 firm (Big10) are positive and significant; the regression coefficient of stock level (Inv) is negatively significant; the complexity of audit services (Sqsub) has a negative correlation with audit quality.

\section{Robustness Test}

\subsection{Variable Substitution}

In order to verify the robustness of the conclusion, dependent variables $|\mathrm{Da}|$ 
were replaced with accounting conservatism (Cscore), which is the positive indicators of the audit quality, which means that accounting conservatism is positively correlated with the audit quality. In the regression result of Table 5 , the regression coefficient of Resfee is -0.0601 with high significance. The data indicates that the higher the abnormal audit fees are, the worse the audit quality is, which is consistent with the hypothesis 1 of this paper. In regression (2), control variable were changed, Resfee has a highly significant regression coefficient of -0.0599 , and this regression result is similar to regression (1), suggesting that there is a negative correlation between abnormal audit fees and audit quality. In regression (3), all the control variables were taken into consideration. Resfee's regression coefficient is -0.0588 , with high significance at $1 \%$ level, indicating that the abnormal audit fees will lower the audit quality. Regression (4) verifies the relationship between positive abnormal audit fees and audit quality. It can be seen that the regression coefficient of Resfee is -0.0583 and highly significant, indicating that the abnormal audit costs will reduce the audit quality. The regression results obviously support the Hypothesis $2 \mathrm{a}$ and are similar to the conclusion made through Table 4. Regression (5) is the result of the negative abnormal audit fees and the audit quality. Resfee's regression coefficient is -0.0437 and highly significant; showing that the negative abnormal audit costs will impair the audit quality, which statistically suppor the hypothesis $2 \mathrm{~b}$. The regression results of the control variables are similar to those in Table 4, therefore no more tautology here.

Table 5. Robustness test of abnormal audit fees and audit quality (1).

\begin{tabular}{|c|c|c|c|c|c|}
\hline & All Resfee & All Resfee & All Resfee & Resfee $>0$ & Resfee $<0$ \\
\hline & (1) & (2) & (3) & (4) & (5) \\
\hline Resfee & $\begin{array}{c}-0.0601^{\star \star *} \\
(-52.41)\end{array}$ & $\begin{array}{c}-0.0599^{* * *} \\
(-48.76)\end{array}$ & $\begin{array}{c}-0.0588^{\star * *} \\
(-52.42)\end{array}$ & $\begin{array}{c}-0.0583^{* * *} \\
(-27.40)\end{array}$ & $\begin{array}{c}-0.0437^{\star * *} \\
(-13.74)\end{array}$ \\
\hline Lev & $\begin{array}{c}0.0587^{\star * *} \\
(12.60)\end{array}$ & & $\begin{array}{c}0.0641^{\star * *} \\
(13.74)\end{array}$ & $\begin{array}{c}0.0619^{\star * *} \\
(8.65)\end{array}$ & $\begin{array}{c}0.0682^{\star * *} \\
(10.99)\end{array}$ \\
\hline Roa & $\begin{array}{c}-0.1689^{\star * *} \\
(-25.04)\end{array}$ & & $\begin{array}{c}-0.1658^{\star * *} \\
(-25.03)\end{array}$ & $\begin{array}{c}-0.1695^{\star * *} \\
(-16.24)\end{array}$ & $\begin{array}{c}-0.1589^{\star * *} \\
(-19.08)\end{array}$ \\
\hline Cashf & $\begin{array}{c}-0.0329^{* * *} \\
(-3.06)\end{array}$ & & $\begin{array}{c}-0.0254^{* *} \\
(-2.36)\end{array}$ & $\begin{array}{c}-0.0517^{\star * *} \\
(-2.90)\end{array}$ & $\begin{array}{c}-0.0023 \\
(-0.18)\end{array}$ \\
\hline Big10 & & $\begin{array}{c}-0.0215^{\star * *} \\
(-12.03)\end{array}$ & $\begin{array}{c}-0.0203^{* * *} \\
(-12.47)\end{array}$ & $\begin{array}{c}-0.0232^{* * *} \\
(-8.35)\end{array}$ & $\begin{array}{c}-0.0166^{\star * *} \\
(-7.97)\end{array}$ \\
\hline Inv & & $\begin{array}{c}0.0467^{\star * *} \\
(7.19)\end{array}$ & $\begin{array}{c}0.0340^{\star * *} \\
(5.41)\end{array}$ & $\begin{array}{c}0.0375^{\star * *} \\
(3.63)\end{array}$ & $\begin{array}{c}0.0275^{\star * *} \\
(3.59)\end{array}$ \\
\hline Sqsub & & $\begin{array}{c}-0.0144^{* * *} \\
(-10.53)\end{array}$ & $\begin{array}{c}-0.0162^{\star * *} \\
(-12.92)\end{array}$ & $\begin{array}{c}-0.0182^{\star * *} \\
(-8.86)\end{array}$ & $\begin{array}{c}-0.0141^{\star * *} \\
(-9.15)\end{array}$ \\
\hline con & & $\begin{array}{c}0.0982^{\star * *} \\
(20.56)\end{array}$ & $\begin{array}{c}0.0785^{\star * *} \\
(15.96)\end{array}$ & $\begin{array}{c}0.0763^{\star * *} \\
(9.69)\end{array}$ & $\begin{array}{c}0.0809^{\star * *} \\
(13.08)\end{array}$ \\
\hline Ind & control & control & control & control & control \\
\hline Year & control & control & control & control & control \\
\hline $\mathrm{f}$ & $255.09^{\star * *}$ & $205.49^{* * *}$ & $257.68^{\star * *}$ & $120.97^{\star * *}$ & $104.00^{* * *}$ \\
\hline adj & 0.5833 & 0.5298 & 0.6102 & 0.6205 & 0.5176 \\
\hline $\mathrm{n}$ & 5083 & 5083 & 5083 & 2202 & 2881 \\
\hline
\end{tabular}

Notes: Significance (two-tailed) at: ${ }^{\star} 0.10,{ }^{*}{ }^{\star} 0.05$ and ${ }^{\star * *} 0.01$ levels, respectively. 
In Table 6, dependent variable was substituted and the abnormal audit fee was measured by the logarithm of annual change value of audit charges. In regression (1), the regression coefficient of Dlnfee is 0.0420 , with relatively high significance at 5 percent. According to the regression result in regression (1), it can be apparently seen that the abnormal audit fees are negatively correlated with the audit quality, which is consistent with Hypothesis 1. In regression (2), the regression coefficient of Dlnfee is 0.0519 , with relatively high significance, which is consistent with regression (1). In regression (3), the regression coefficient of Dlnfee is 0.0407 and is relatively significant. Analysis in Regression (1), regression (2), and regression (3) shows that the abnormal audit fees will hinder the audit quality, which is consistent with the regression results in Table 4 and Table 5. However, the regression coefficient level in Table 6 is less significant than in Table 4 and Table 5. Regression (4) is the regression result of positive abnormal audit fees and audit quality. Dlnfee's regression coefficient of 0.0299 and is relatively significant, indicating that the abnormal audit costs have negative influence on the audit quality. Similarly, in regression (5), the negative exception audit cost regression coefficient is 0.1238 and relatively significant; suggesting that negative abnormal audit costs will degrade the audit quality. For other control variables, since the coefficient value and significance level are similar to those in previous analysis, no more tautology here.

Table 6. Robustness test of abnormal audit fees and audit quality (2).

\begin{tabular}{cccccc}
\hline & All Dlnfee & All Dlnfee & All Dlnfee & Dlnfee $>0$ & Dlnfee $<0$ \\
\hline \multirow{2}{*}{ Dlnfee } & $(1)$ & $(2)$ & $(3)$ & $(4)$ & $(5)$ \\
& $0.0420^{* *}$ & $0.0519^{* * *}$ & $0.0407^{* *}$ & $0.0229^{* *}$ & $0.1238^{* *}$ \\
& $(2.32)$ & $(2.85)$ & $(2.25)$ & $(2.34)$ & $(1.99)$ \\
Lev & $0.2939^{* * *}$ & & $0.3058^{* * *}$ & $0.3801^{* * *}$ & $0.4508^{* * *}$ \\
& $(12.02)$ & & $(12.10)$ & $(8.93)$ & $(4.28)$ \\
Roa & $0.1467^{* * *}$ & & $0.1585^{* * *}$ & $0.2384^{* * *}$ & $0.3019^{*}$ \\
& $(3.73)$ & & $(4.01)$ & $(3.20)$ & $(1.93)$ \\
Cashf & 0.0662 & & 0.0233 & 0.0266 & 0.2096 \\
& $(1.04)$ & & $(0.36)$ & $(0.24)$ & $(0.75)$ \\
Big10 & & $0.0264^{* * *}$ & $0.0210^{* *}$ & $0.0262^{*}$ & 0.0246 \\
& & $(2.81)$ & $(2.26)$ & $(1.75)$ & $(0.62)$ \\
Inv & & -0.0262 & $-0.1293^{* * *}$ & $-0.1363^{* *}$ & -0.2372 \\
& & $(-0.73)$ & $(-3.47)$ & $(-2.14)$ & $(-1.41)$ \\
Sqsub & & $0.0245^{* * *}$ & $0.0149^{* *}$ & $0.0268^{* *}$ & 0.0049 \\
& & $(3.34)$ & $(2.03)$ & $(2.29)$ & $(0.16)$ \\
con & $-0.0875^{* * *}$ & 0.0279 & $-0.1145^{* * *}$ & $-0.2245^{* * *}$ & -0.0923 \\
Ind & $(-3.31)$ & $(1.02)$ & $(-3.82)$ & $(-4.30)$ & $(-0.72)$ \\
Year & control & control & control & control & control \\
f & control & control & control & control & control \\
adj & $39.26^{* * *}$ & $34.10^{* * *}$ & $36.34^{* * *}$ & $17.17^{* * *}$ & $5.45^{* * *}$ \\
$\mathrm{n}$ & 0.1387 & 0.1223 & 0.1410 & 0.1347 & 0.1797 \\
& 6889 & 6889 & 6889 & 3221 & 590 \\
\hline
\end{tabular}

Notes: Significance (two-tailed) at: ${ }^{*} 0.10,{ }^{*} 0.05$ and ${ }^{* * *} 0.01$ levels, respectively. 


\subsection{Other Issues to Be Considered}

Clustering may happen when performing regression. Since the Pooled data we used is intertemporal, the sample company reluctantly appears in the regression, resulting in clustering phenomenon and accordingly leads to underestimation of the standard error and overestimation of the significance level. Therefore, we referred the practice of Petersen, re-performed regression with hierarchical clustering and heteroscedasticity being control, the results did not change significantly.

Distinguish the direction of audit quality. Since the dependent variable is the absolute value of the discretionary accruals, the discretionary accruals are divided into two categories according to the direction, and then operate the regression. Results shows that positive abnormal audit fees are positively correlated with positive discretionary accruals and negative abnormal audit fees has positive correlation with the discretionary accruals, which authenticates our conclusions.

In the above analysis, we replace the independent variables and dependent variables respectively to verify the robustness of the conclusions of this paper; and a variety of means was adopted to avoid the impact of endogenous problems on the conclusions. Moreover, the effects of self-selection bias are also taken into consideration. To sum up, all the above measures are taken to prove the validity of our conclusions.

\section{Conclusions}

Companies employ auditors and pay audit fees, which actually constitutes an economic bond between auditors and companies. And the impact of this economic dependency on audit quality has become a hot issue in audit research. This paper examines the impact of auditors' excessively high or low abnormal audit fees on audit quality. The research adopted the data of China listed companies from 2007-2013, co-opted the abnormal audit fee model of Chen et al. (2005), Asthana and Boone (2012), and Blankley (2012), and finally discovered that there are abnormal audit fees in Chinese listed companies and its existence debases the audit quality. After considering the direction of the abnormal audit fee, empirical results show that the positive abnormal audit fees have negative correlation with audit quality, which demonstrates that auditors' collection of high audit fees does not only impair the audit independence, but also acquiesce companies' earnings management behavior, and finally jeopardizes audit quality. We also found that negative abnormal audit fees and audit quality are negatively correlated, indicating that the firm's strong bargaining power will reduce the auditor's audit fees and audit quality; simultaneously, lower audit fees will also impel auditors to reduce audit efforts, such as cutting substantive analysis and testing to control audit costs for profitability.

Unavoidably, there are still some limitations of this paper. Due to difficulty in the acquisition of certain data, the effects of auditors' composition, the distribution of audit work, and internal audit on the audit quality are not considered, 
which may weaken the conclusions of this paper. Still, this is the direction of author's follow-up research.

\section{References}

[1] Gibbins, M., Salterio, S. and Webb, A. (2001) Evidence about Auditor-Client Management Negotiation Concerning Client's Financial Reporting. Journal of Accounting Research, 39, 535-563. https://doi.org/10.1111/1475-679X.00027

[2] Casterella, J., et al. (2004) Auditor Industry Specialization, Client Bargaining Power, and Audit Pricing. Auditing. A Journal of Practice \&Theory, 23, 123-140.

https://doi.org/10.2308/aud.2004.23.1.123

[3] Chen, J.P., Su, J.X. and Wu, X. (2005) Abnormal Audit Fees and the Improvement of Unfavorable Audit Outcomes. China Accounting and Finance Review, No. 4, 1-54. (In Chinese)

[4] Mitra, S., Deis, D. and Hossian, M. (2009) The Association between Audit Fees and Reported Earnings Quality in Pre- and Post-Sarbanes-Oxley Regimes. Review of Accounting and Finance, 8, 232-253. https://doi.org/10.1108/14757700910980840

[5] Krishnan, J. (2005) Audit Committee Quality and Internal Control: An Empirical Analysis. The Accounting Review, 80, 649-675.

https://doi.org/10.2308/accr.2005.80.2.649

[6] Asthana, S. and Boone, J. (2012) Abnormal Audit Fee and Audit Quality. Auditing: A Journal of Practice \&Theory, 31, 1-22. https://doi.org/10.2308/ajpt-10294

[7] Simunic, D. (1980) The Pricing of Audit Services: Theory and Evidence. Journal of Accounting Research, 18, 161-190. https://doi.org/10.2307/2490397

[8] Krishnan, J., Rama, D. and Zhang, Y. (2008) Costs to Comply with SOX Section 404. Auditing: A Journal of Practice \&Theory, 27, 169-186. https://doi.org/10.2308/aud.2008.27.1.169

[9] Zhang, Y.X. (2011) Factors Influencing Audit Fees of Internal Control over Financial Reporting: Empirical Research Based on Chinese Companies Listed in the USA. Accounting Research, No. 12, 70-77. (In Chinese)

[10] Li, M.H., Zhang, J. and Liu, X.X. (2012) The Effect of Audit Firm Mergers on Audit Pricing: Evidence from Chinese Stock Market. Accounting Research, No. 5, 86-92+94. (In Chinese)

[11] DeAngelo, L. (1981) Auditor Independence, "Low Balling”, and Disclosure Regulation. Journal of Accounting and Economics, 3, 113-127. https://doi.org/10.1016/0165-4101(81)90009-4

[12] Larcker, D. and Richardson, S. (2004) Fees Paid to Audit Firms, Accrual Choices, and Corporate Governance. Journal of Accounting Research, 42, 625-658. https://doi.org/10.1111/j.1475-679X.2004.t01-1-00143.x

[13] Fang, J.X. and Hong, J.Q. (2008) Abnormal Audit Fees and the Shredded Audit Quality: Evidence from China's Public Companies. China Accounting Review, No. 4, 425-441. (In Chinese)

[14] Hribar, P., Kravet, T. and Wilson, R. (2010) A New Measure of Accounting Quality. SSRN, Working Paper.

[15] Blankley, A., Hurtt, D. and MacGregor, J. (2012) Abnormal Audit Fees and Restatements. Auditing. A Journal of Practice \& Theory, 31, 79-96.

https://doi.org/10.2308/ajpt-10210

[16] Dechow, P., Sloan, R. and Sweeny, A. (1995) Detecting Earnings Management. Accounting Review, 70, 193-225. 
[17] Khan, M. and Watts, R. (2009) Estimation and Empirical Properties of a Firm-year Measure of Accounting Conservatism. Journal of Accounting\& Economics, 48, 132150. https://doi.org/10.1016/j.jacceco.2009.08.002

Submit or recommend next manuscript to SCIRP and we will provide best service for you:

Accepting pre-submission inquiries through Email, Facebook, LinkedIn, Twitter, etc. A wide selection of journals (inclusive of 9 subjects, more than 200 journals)

Providing 24-hour high-quality service

User-friendly online submission system

Fair and swift peer-review system

Efficient typesetting and proofreading procedure

Display of the result of downloads and visits, as well as the number of cited articles

Maximum dissemination of your research work

Submit your manuscript at: http://papersubmission.scirp.org/

Or contact ojacct@scirp.org 